\title{
Kommentar
}

\section{Å få en forklaring}

Eline Feiring skriver i en fin og tankevekkende artikkel om sine erfaringer med å leve med en plagsom tilstand som fortsatt er lite kjent og antakelig underdiagnostisert. Hun merket plager allerede i niårsalderen med uro, parestesier og behov for å bevege beina.

Symptomene ved denne tilstanden ble beskrevet av den engelske legen Thomas Willis (1621-75) allerede i 1672. Betegnelsen «restless legs syndrome» (RLS) ble først brukt av den svenske kirurgen Karl A. Ekbom (1907-77) i 1945. På norsk kalles tilstanden for rastløse bein (1).

Søvnrelatert bevegelsesforstyrrelse Rastløse bein er nå inkludert i The International Classification of Sleep Disorders (ICSD-2) blant søvnrelaterte bevegelsesforstyrrelser. Tilstanden kjennetegnes av et sterkt ubehag i leggene som opptrer i hvile, som oftest om kvelden og natten, og som forsvinner ved bevegelse.

Forekomsten antas å være 5-10\%. Den underliggende årsaken er fortsatt ikke fullt ut forstått, men det dopaminerge systemet er sannsynligvis involvert, og medikamenter som øker dopamininnholdet eller som stimulerer dopaminerge reseptorer kan ha god effekt på plagene.

Fordi jernmangelanemi ofte forekommer ved rastløse bein, antar man at jern kan ha betydning i patogenesen. Det er derfor viktig at man korrigerer for en jernmangelanemi. Jernlagrene bør være fulle før man ev. vurderer å gi mer spesifikk behandling for rastløse bein. Der det er en primær årsak, må denne identifiseres og behandles for symptomatisk behandling iverksettes.

Rastløse bein interfererer oftest med søvnen og disponerer dermed for andre sykdommer og kan i tillegg gi redusert livskvalitet. Jeg har møtt pasienter som utviklet depressive symptomer sekundært til plagene i beina, og kanskje spesielt sekundært til søvnplagene. Mange av disse ble kvitt sine depressive symptomer da de fikk behandling mot rastløse bein.

\section{Diagnostikk og behandling}

Det tok 20 år før Eline Feiring i 2003 selv fant frem til diagnosen og senere fikk den bekreftet av nevrolog. At det tar lang tid fra symptomene blir plagsomme til diagnosen blir stilt, er nok dessverre vanlig. Å få symptomdebut allerede i ni års alder er tidlig, selv om mer enn en tredel får plager før 20 års alder. Blant dem som får tilstanden i ung alder, er det ofte en familiær forekomst.

Tilstanden har gjennom årene gitt opphav til mange kjerringråd, trolig også til dyre og spekulative alternative behandlingstilbud. Eline Feirings symptomer er relativt klassiske, og det er typisk at mange pasienter drar nytte av temperaturstimulering, f.eks. varme eller kalde bad, eller massasje av beina, og dette anbefales som ikke-medikamentelle tiltak.

Eline Feirings plager målt med et av våre måleinstrumenter (spørreskjema) viser at hun er moderat til alvorlig rammet av rastløse bein. De fleste vil da anbefale at man forsøker behandling med en dopaminagonist, forutsatt at eventuelle sekundære årsaker er utelukket eller adekvat behandlet. Men det må naturligvis bli opp til pasienten selv om man ønsker å prøve slike medikamenter.

\section{Morten I. Lossius}

morten.lossius@epilepsy.no

Barne- og ungdomsavdelingen

Epilepsisenteret - SSE

Nevroklinikken

Oslo universitetssykehus, Rikshospitalet

0027 Oslo

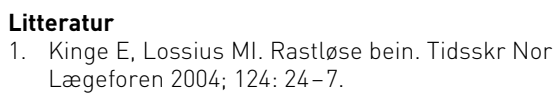

Manuskriptet ble mottatt 6.8. 2009 og godkjent 13.8. 2009. Medisinsk redaktør Anne Kveim Lie. 